\title{
PACKAGE OF BIRTHING BALL, PELVIC ROCKING, AND ENDORPHIN MASSAGE (BPE) DECREASE THE FIRST STEP LABOR PAIN
}

\author{
(Paket Bola Persalinan, Pelvic Rocking, Dan Pijat Endorphin (P. B. P) Menurunkan Nyeri \\ Persalinan Kala I)
}

\author{
Nila Marwiyah, Lenny Stia Pusporini ${ }_{2}$ \\ Lecture of Maternity Nursing Science, Faletehan Health Science Institute, Serang, Banten, Indonesia \\ E-mail: nila_marwiyah@yahoo.com
}

\begin{abstract}
ABSTRAK
Pendahuluan. Nyeri persalinan merupakan pengalaman tidak menyenangkan dan menakutkan bagi ibu yang melahirkan. Nyeri yang terjadi dapat menimbulkan rasa takut, kelelahan, dan trauma persalinan pada ibu. Penggunaan bola persalinan, dan melakukan pelvic rocking (menggoyang panggul), dan pijat endorphin, merupakan salah satu metoda nonfarmakologi yang dapat dilakukan untuk mengurangi nyeri persalinan. Tujuan penelitian ini untuk mengetahui pengaruh Paket Bola Persalinan, Pelvic Rocking, dan Pijat Endorphin (B.P.P) terhadap nyeri persalinan Kala I. Metode. Penelitian menggunakan desain Quasi Eksperimental. Sampel dalam penelitian 23 ibu dalam proses persalinan, dengan teknik sampling kuota. Instrumen penelitian menggunakan Numeric rating Scale(NRS). Hasil.Hasil uji paired sample t-test diperoleh ada perbedaan bermakna terhadap nyeri persalinan antara sebelum dan setelah dilakukan intervensi dengan nilai $\mathrm{p}<0,01$. Diskusi. Diharapkan dari penelitian ini dapat memberikan informasi tentang pentingnya melakukan manajemen nyeri non farmakologis seperti bola persalinan, pelvic rocking (menggoyang panggul), serta pijat endorphin untuk membantu mengurangi nyeri persalinan pada kala 1 . Penelitian lebih lanjut perlu diteliti mengenai variable kecemasan pada ibu bersalin.
\end{abstract}

Kata Kunci: Nyeri persalinan, Paket Bola Persalinan, Pelvic Rocking, dan Pijat Endorphin (B.P.P), Proses persalinan

\begin{abstract}
Introduction: Labor pain is an unpleasant and frightening experience for the birth mother. In addition, labor pain causes exhaustion and childbirth trauma. Birthing ball, pelvic rocking, and endorphin (B.P.E) massage are emerging as nonpharmacology methods of pain management in labor. The aimed of this study was to investigate the effect of a package of $B P E$ on labor pain during the first stage of labor. Method: This study was quasi-experiment. Total numbers of samples were 23 mothers who were in the first stage of labor. Samples were selected by using quota sampling technique. The instrument of this study was numeric rating scale (NRS). Result: Data analysis by using paired sample t-test revealed that there were significantly different between before and after the intervention of BPE on labor pain during the first stage of labor in this study ( $p<0.01)$. Discussion: This study showed that BPE is effective as non-pharmacology methods on pain reliever of the first stage of labor. Further study needs to investigate other variables such as anxiety of birth mother.
\end{abstract}

Keywords: labor pain, package of birth ball, pelvic rocking, and endorphin massage (BPE), labor process.

\section{INTRODUCTION}

Labor is a processing of fairly month conception products (fetus and placenta)or which can live outside the womb through the birth canal or another way with or without assistance (Murray and Mckinney, 2014). A normal labor process is initiated by uterine contraction which is the power to push fetus and to groan. Uterine contraction is a contraction of womb muscles in labor (Rohani, Saswita, and Marisha, 2011). The alteration caused by uterine contraction is flat and open cervix and womb ischemia which might cause pain. More volume and frequency of uterine contraction causes more severe pain; the peak of pain occurs in an active phase in which complete cervical dilation reaches $10 \mathrm{~cm}$ (Reeder, Martin \& Griffin, 2011).

Labor pain occurs when contraction exists and goes away after contraction. The intensity of the pain is very individual, influenced by perception, mental support, labor companion, and pain management technique. In labor process, experiencing the pain is considered as the most unpleasant even the most frightening by mothers. The pain can influence mother condition to be tired, scared, worried, and stressful (Floris and Irion, 
2012). Stress can weaken uterine contraction and can cause a long labor (Adam, EberhardGran \& Eskild, 2012). Therefore, labor pain management is needed to avoid an unexpected condition. It can be a pharmacological and non-pharmacological pain management. Nonpharmacological pain management is a method without using drugs, by not slowing down labor process and not causing allergy (Reeder Martin $\&$ Griffin, 2011). There are many methods of non-pharmacological pain management such as birthing ball, pelvic rocking, and endorphin message (Aprillia, 2011)

The birthing ball can be used as a tool to sit down in labor process as it can support perineum to have low pressure and keep fetus parallel to the pelvis (Aprilia, 2011). According to Aprilia (2011), pelvic rocking is a movement of the rocking pelvis to the front, back, left, and right. The movement aims to release uncomfortable feeling in the labor process. Using the birthing ball and pelvic rocking at the same time is very useful to strengthen muscles of the abdomen and lower back, to release pain, and to facilitate more effective contraction.

A study conducted by Retnaningtyas et al. in 2013 about the relationship of pelvic rocking and birthing ball to the maternal duration of the first stage in Griya Hamil Sehat Mejasem (a maternity clinic) shows that implementing pelvic rocking and birthing ball relates to phase I duration. It is able to expedite labor process particularly in the first stage and to help mothers have a normal phase I.

The intervention can be modified by doing endorphin massage. Endorphin hormone which is usually produced when being stress or sick helps to release pain and contributes to mother's euphoria during labor process (Reeder Martin \& Griffin, 2011). Endorphin massage is a technique of soft touch, which can be used to release uncomfortable feeling during labor process and to improve relaxation by stimulating a comfortable feeling through skin surface (Aprillia, 2011).

The prior study conducted at Serang Kota Public Health Center (Ina. Puskesmas) involves 10 patients who were in labor into the interview. The result shows that 2 patients told a severe pain, 4 patients said that they had a moderate pain and were just able to rub their back, to pray, and to surrender with the pain, and 4 others said that their pain was light as they had experienced it in the previous labor and trusted health officers who helped them. Based on the background, some nonpharmacological interventions which have been examined impacts on the pain. Thus, the researchers intended to make a package of interventions by combining birthing ball, pelvic rocking, and endorphin massage (BPE). Therefore, the researchers were interested in examining the effect of the package of a birthing ball, pelvic rocking, and endorphin massage (BPE) to labor pain of the first stage. Moreover, the specific intention of the study is to identify labor pain before and after intervention and to identify the effect of the package of a birthing ball, pelvic rocking, and endorphin massage to labor pain of the first stage.

\section{HEORETICAL FRAMEWORK}

Labor process is started when first uterine contraction happens and further uterine works hard to dilate for next hours until a baby born (Reeder, Martin, Koniak-Griffin, 2011). When labor process occurs, a mother has uterine contraction specifically in the first active stage and a transitional stage. Uterine contraction felt by a birthing mother causes unpleasant in a lower back area spreading to the abdominal area, which is similar to menstrual pain (Murray \& Mckinney, 2014). In active first phase, a mother gets serious pain and cannot control it; thus, she needs more supports and encouragements (Chapman \& Durman, 2010).

Labor pain can stir birthing mother to stress which causes excessive hormone secretion such as catecholamine and steroid. The hormones can trigger smooth muscles strain and vasoconstriction of blood vessels, which decrease uterine contraction, decrease blood circulation from uteroplacental to uterine, and causes uterine ischemic which highly increases pain impulses (Pilliteri, 2010). According to Laursen, Johansen, and 
Hedegaard (2009), many pregnant women have a fear of being at high risk to have cesarean delivery and dystonia. Labor process can run well and easier if the birthing mother is relaxed and confident in her ability to overcome the pain and able to find a way to release contraction pain (Klosnner \& Hatfied, 2010).

According to Kinz and Eliasson (2010), their study to 67 primiparas in Sweden shows that the active role of husband, midwife, nurse, and doctor in monitoring the increase of labor pain can help the mother to release the pain. Maternity nurses have a role as an educator for birthing mother and her family in order to help her release the labor pain. The pain management can be pharmacologic and nonpharmacologic. There are some methods of non-pharmacological pain management namely birthing ball, pelvic rocking, and endorphin massage (Aprillia, 2011).

A birthing ball is a method done to release labor pain. In stage I of labor process, a birthing mother sitting down with an upright position on the ball is proven to increase blood circulation to womb, placenta, and fetus, to widen pelvic surface, to push baby head down, to relax pelvis, and to release uncomfortable feeling during pregnancy (Aprillia, 2011). It is parallel with the study of Leung et al. (2013) that birthing ball done for 30 minutes is effective to decrease labor pain with a $p$ value $<0,005$.

Pelvic rocking is a movement used to release uncomfortable feeling during the labor process. The benefits are to strengthen abdominal muscles and lower back muscles, to release pressure in blood vessels of the womb and in the bladder, to improve relaxation, and to help drop the lowest part of the fetus (Aprilia, 2011). It is parallel with the study of Handajani (2013) who stated that pelvic rocking training for the birthing mother has significant effect to labor pain decrease. It is also similar with Zaky (2016) who wrote that the implementation of pelvic rocking and birthing ball help releases labor pain; the decreasing pain and the comfort felt by the birthing mother can accelerate labor process.
Endorphin massage is a method to stimulate the production of endorphin hormone in the body. Endorphin is the hormone which functions as natural pain remover. Endorphin massage can be used to decrease uncomfortable feeling during labor process and to increase relaxation by stimulating comfortable feeling through the skin surface. The very soft massage technique can improve the release of oxytocin, which facilitates labor process. It is suited with Gallo et al. (2013) who conducted a study to 43 birthing mothers with cervical dilatation $4-5 \mathrm{~cm}$. They stated that giving a birthing mother 30 minutes massage can be an effective way to labor pain.

\section{METHOD}

The study employs quasi-experimental design with one group pretest and post-test design which is usually used for a field study. The design does not employ a control group, but at least first observation (pretest) had been implemented, which enabled the researchers to examine the alteration happened after the experiment (program). The observation conducted before the experiment (01) is called pre-test, and the one after the experiment (02) is called post-test.

The dependent variable in this research is labor pain of the first stage, and the independent one is the intervention of package of a birthing ball, pelvic rocking, and endorphin massage. The population is whole maternal at Public Health Center Serang City and Public Health Center Singandaru. The sample is whole maternal who fulfilled inclusion criteria namely a term pregnant mother with a singleton pregnancy, cephalic presentation (36-42 weeks), normal birth plan, and having childbirth signs with cervical dilation $4-8 \mathrm{~cm}$. Meanwhile, the exclusion criteria are a term pregnant mother with multiple pregnancies, abnormal fetal presentation either breech, oblique or latitude, high-risk pregnancy with diseases such as preeclampsia, cardiac disease, and lung disease, premature rupture of membranes, infection, childbirth process is 
predicted using tools such as vacuum, forceps, or surgery, mother with narrow pelvis, mother with uterine contraction abnormalities either primary or secondary uterine inertia, and mother with cervical dilation $<4$ and $>8$.

The sample is 23 respondents who were selected by using quota sampling technique in which sample is determined from a population which has specific characters until reaching a required size (quota). The data is primary and collected from respondents. In this study, the instrument of data collection is Numeric Rating Scale (NRS) which is used as pain scale assessment. Data analysis was done by using univariate analysis.

Univariate analysis was conducted to the variable of labor pain scale. Meanwhile, bivariate analysis was done to investigate the effect of the package of a birthing ball, pelvic rocking, and endorphin massage to first stage labor pain. Before conducting the statistical test, the researchers did a test of data normality to examine whether the data is normally distributed or not. If the data is normally distributed, the statistical test used will be dependent paired t-test, but if it is not normal, the statistical test used will be Wilcoxon. If the $p$ value of statistical test result is $\leq \alpha(0.05)$, Ho will be rejected, and if the $p$ value is $>\alpha(0.05)$, Ho will not be rejected, which means that there is no significant difference.

\section{RESEARCH IMPLEMENTATION}

The research process was started by collecting prior data from information in
Serang region.After capturing phenomena, the researchers wrote a research proposal and a research letter for Health Department of Serang City, forwarded to 2 Public Health Center namely Public Health Center Serang City and Public Health Center Singandaru. The licensing process of conducting research was done to both Public Health Centers. Then, the researchers determined the sample size which was suited to inclusion criteria. The researchers obtained 10 respondents in Public Health Center Singandaru and 13 respondents in Public Health Center Serang City. Thus, the total samples are 23 respondents.

The respondents coming to the Public Health Center and fulfill inclusion criteria firstly did a labor pain check before getting intervention. Then, the birthing mothers were given the intervention of birthing ball, pelvic rocking, and endorphin massage for 30 minutes while having labor pain. After that, labor pain assessment was conducted after giving the intervention. Finally, after collecting the required data, the researchers processed the data by using computerization system.

\section{RESULT}

According to Table 1, the obtained data showed that the average labor pain before intervention is 6.57 with standard deviation 0.843 ; meanwhile, the average labor pain after the intervention is 6.13 with standard deviation 0.920 . What the average score of paired t-test results in table 2 is 0.435 , the standard deviation is 0.662 , the $p$ value is 0.005

Table 1.Frequency Distribution of Labor Pain before and after Intervention

\begin{tabular}{lllll}
\hline \multicolumn{1}{c}{ Labor Pain } & & Mean & Standard Deviation & Standard Error \\
\hline Pre test & 6.57 & & 0.843 & 0.176 \\
Post test & 6.13 & 0.920 & 0.192 \\
\hline
\end{tabular}

Table 2. The Effect of the Package of Birthing Ball,Pelvic Rocking, and Endorphin Massage to First Stage Labor Pain

\begin{tabular}{lccccccr}
\hline & \multicolumn{9}{c}{ Paired difference } & 95\% CI & \multirow{2}{*}{ t } & P \\
\cline { 2 - 7 } & Mean & SD & SE & Lower & Upper & & \multirow{2}{*}{0.148} \\
\hline $\begin{array}{l}\text { Pre test } \\
\text { Post test }\end{array}$ & 0.435 & 0.662 & 0.138 & 0.148 & 0.721 & \multirow{2}{*}{0.005} \\
\hline
\end{tabular}


and calculated $t$ value is 3.148 . The data shows that the package of a birthing ball, pelvic rocking, and massage endorphin contributes to a significant influence to first stage labor pain.

The research was conducted to 23 giving birth mothers as respondents who had labor pain which was assessed by using Numeric Rating Scale(NRS). The result of the study shows that the mean score of labor pain before intervention is 6.57 .

\section{DISCUSSION}

The pain that is giving birth mothers have comes from uterine contraction and cervical dilatation, which normally happens to them. Reeder, Martin, and Griffin (2011) stated that the pain felt stronger indicates an improving frequency of uterine contraction which accelerates cervical dilatation. However, the pain is different for each mother. It depends on her perception, mental support, and pain management technique.

Labor pain felt by giving birth mother can cause stress (Floris and Iron, 2012). A stressful condition during labor process can give a negative effect on the mother. Uterine contraction is weakened, which results in a longer duration of labor (Adam, EberhardGran, and Eskild, 2012). Therefore, to prevent the mother from a long partum needs a nursing intervention which is able to decrease labor pain. One of them is by non-pharmacological management.

Non-pharmacological management is a method conducted without using drugs, which does not slow down labor process and does not cause allergy to giving birth mothers (Reeder, Martin Griffin, 2011). The method of pain management in this study is by using a birthing ball, pelvic rocking, and endorphin massage.

A birthing ball is used as sitting instrument, which is able to give support to perineum without a lot of pressures and to keep fetus parallel with pelvis (Aprillia, 2011). When a birthing mother sits down on a birthing ball, she can do a pelvic rocking by shaking her pelvis to the front, back, left and right. Pelvic rocking aims to release labor pain, to strengthen abdominal and lower back muscles, and to help contraction more effective. Then, the movement is added by a soft endorphin massage which intends to release an uncomfortable feeling during labor process and to improve relaxation. Endorphin massage can stimulate endorphin hormone which helps to release labor pain and to prevent the mother from stress.

Based on the study result, the mean score of labor pain after the intervention is 6.13. In addition, based on paired t-test result by comparing labor pain before and after the intervention, it is obtained that $p$ value is 0.005 and the mean score is 0.435 which indicates a significant difference between before and after the intervention of using a birthing ball, pelvic rocking, and endorphin massage during first stage labor pain. The result shows that the intervention of package of a birthing ball, pelvic rocking, and endorphin massage impacts on first stage labor pain.

The result is suitable for the study of Leung et al. (2013) who stated that giving the birthing ball for 30 minutes is effective to release labor with a $p$ value $<0.005$. According to Zaky (2016), implementing pelvic rocking and birthing ball helps to release labor pain; the released pain and comfortable feeling which a birthing mother gets can accelerate labor process. Endorphin massage is also able to stimulate endorphin hormone; thus, it can improve comfort and release labor pain. It is parallel with the study of Gallo et al. (2013) who shows that a 30 minutes massage given to birthing mothers in cervical dilation $4-5$ $\mathrm{cm}$ is effective to release labor pain.

\section{CONCLUSION}

The package of a birthing ball, pelvic rocking, and endorphin massage (BPE) is effective to release labor pain of a birthing mother in first stage.

For further study, variable of maternal anxiety should be added and supported by respondent characteristics. (PDPI 2011; Notoatmodjo 2003) 


\section{REFERENCES}

A. (2012). Fear of childbirth and duration of labour: a study of 2206 women with intended vaginal delivery. BJOG;119:1238-1246. doi: 10.1111/ j.1471-0528.2012.03433.x.

Aprilia, Y. (2011). Gentel Birth: Melahirkan Nyaman Tanpa Rasa Sakit. Jakarta: PT. Duta Prima

Arikunto,S. (2006). Prosedur penelitian suatu pendekatan praktik. Jakarta: Rineka Cipta.

Chapman, L; Durham, R. (2010). Maternalnewborn nursing: The critical components of nursing care. Philadelphia: E.A Davis company

Floris, L, \& Irion O. (2012). Association between anxiety and pain in the latent phase of labour upon admission to the maternity hospital: A prospective, descriptive study. J Health Psychol. Diambil pada tanggal 29 Oktober di http://www.ncbi.nlm.nih.gov/ pubmed $/ 24155186$

Gallo, R.B.S; Santana, L.S; Ferreira, C.H.J; Marcolin, A.C; Polineto, O.B; Duarte, G; Quintana, S.M. (2013). Massage reduced severety of pain duing labor:: a randomized trial. Journal Phisyotherapy. Volume 59; 109-116.

Handajani (2013). Pengaruh Pelvic Rocking terhadap Pengurangan Nyeri Pinggang Persalinan Kala 1 dan Lama Waktu Persalinan Kala II di RSU PKU Muhammadiyah Delanggu. Jurnal Terpadu Ilmu Kesehatan, Volume 2, Nomor 2, Nopember 2013, hlm.41-155.

Kainz, G; Eliasson, M; Von, P. I .(2010). The child's father, an important person for the mother's well-being during the childbirth: A hermeneutic study. Health Care Women Int.31(7):621-35. doi: 10.1080/07399331003725499

Klosnner, N.J; Hatfied, N.T. (2010).Introductory maternity \& pediatric nursing. 2nd ed. Philadelphia: Lippincott Williams \& Wilkins
Laursen M, Johansen C, Hedegaard M. (2009). Fear of childbirth and risk for birth complications in nulliparous women in the Danish National Birth Cohort. BJOG;116:1350-1355. http://www.ncbi. nlm.nih.gov/pubmed/19538412

Leung, R.W. C; Lee, J; Leung, M; Fung, B; Fung, L; Tai, M;........Leung W. (2013). Efficacy of birth ball exercises on labour pain management. Hong Kong Med J. 19:393-9. DOI: $10.12809 / \mathrm{hkmj} 133921$

Murray, S.S; Mckinney, E.S. (2014). Foundations of maternal-newborn and women's health nursing 6th edition. St. Louise: Elsevier saunders.

Pilliteri, A. (2010). Maternal \& child health nursing: Care of the childbearing and childrearing famili ( $6^{\text {th }}$ ed). Philadelpia: Lippincott Williams \& Wilkins.

Reeder, S.J; Martin, L. L; Koniak-Griffin, D .(2011). Keperawatan maternitas: Kesehatan wanita, bayi dan keluarga. Volume 1 Edisi 18. (Yati Afriyati, Imami Nur Rachmawati, Sri Djuwitaningsih, penerjemah). Jakarta: EGC

Retnaningtiyah, D., Sucipto, E., Chikmah, A.M. (2013). Hubungan pelaksanaan pelvic rocking dengan birthing ball terhadap lamanya kala I pada ibu bersalin di Griya Hamil Sehat Mejasem. http:// DGLAJ:ejournal.poltektegal. ac.id/index.php/siklus/article/ download/206/201

Ricci, S.S. (2009). Essential of maternity, and women,s health nursing. Philadelpihia: Lippincott William \& Wilkins.

Rohani, Saswita, S., Marisah. (2011). Asuhan Kebidanan pada Masa Persalinan. Jakarta: Salemba Medika

Zaky, N.H. (2016). Effect of pelvic rocking exercise using sitting position on birth ball during the first stage of labor on its progress. IOSR Journal of Nursing 